\title{
Natural and Artificial Radionuclides in River Bottom Sediments and Suspended Matter in the Czech Republic in the Period 2000-2010
}

\author{
Eduard Hanslik ${ }^{1}$, Diana Marešová ${ }^{1}$, Eva Juranová ${ }^{1,2}$ \\ ${ }^{1}$ Department of Radioecology, T. G. Masaryk Water Research Institute, Public Research Institution, Prague, Czech Republic; \\ ${ }^{2}$ Faculty of Science, Institute for Environmental Studies, Charles University, Prague, Czech Republic. \\ Email: eduard hanslik@vuv.cz
}

Received November $29^{\text {th }}, 2013$; revised December $28^{\text {th }}, 2013$; accepted January $27^{\text {th }}, 2014$

Copyright (c) 2014 Eduard Hanslík et al. This is an open access article distributed under the Creative Commons Attribution License, which permits unrestricted use, distribution, and reproduction in any medium, provided the original work is properly cited. In accordance of the Creative Commons Attribution License all Copyrights (C) 2014 are reserved for SCIRP and the owner of the intellectual property Eduard Hanslík et al. All Copyright (c 2014 are guarded by law and by SCIRP as a guardian.

\section{ABSTRACT}

The concentrations of natural radionuclides, radium-226, radium-228, and potassium-40, and the artificial radionuclide caesium-137, in river bottom sediments and suspended matter were monitored in the Czech Republic by the Czech Hydrometeorological Institute during the period 2000-2010 and 2001-2010 respectively. The data were used to evaluate the natural background levels of these radionuclides and the impact of human activities on the water environment. For potassium-40 in sediments, the natural background level was estimated to be 570 $\mathrm{Bq} / \mathrm{kg}$. To evaluate the background level for radium-226, the river sites affected by human activities (mining and processing uranium ore, coal) were eliminated from the assessment. The average natural background values were $47.8 \mathrm{~Bq} / \mathrm{kg}$ for radium-226 and $47.2 \mathrm{~Bq} / \mathrm{kg}$ for radium-228 in sediments and $86.5 \mathrm{~Bq} / \mathrm{kg}$ for radium-226 and $87.9 \mathrm{~Bq} / \mathrm{kg}$ for radium-228 in suspended matter. The river sediments were identified as good indicators of radioactive contamination, especially radium-226, which recorded historic contamination due to former uranium mining and milling. The radium-226 contamination rate was assessed using the ratio of radium-226 to radium-228. This ratio was used to classify sediment according to the relative contamination from the uranium industry. The residual contamination of caesium-137 due to the Chernobyl accident in 1986 was also assessed. Average values of caesium-137 were $14.0 \mathrm{~Bq} / \mathrm{kg}$ in sediments and $25.0 \mathrm{~Bq} / \mathrm{kg}$ in suspended matter.

\section{KEYWORDS}

River Bottom Sediments; Suspended Matter; Surface Water; Uranium Industry; Radioactive Contamination; Radium-226; Radium-228; Potassium-40; Caesium-137

\section{Introduction}

Monitoring of radioactive substances in river bottom sediments in the Czech Republic has a long history [1-4]. The permanent monitoring of river bottom sediments and suspended matter, which includes gamma-spectrometric analysis, was initiated in 1999 under a programme carried out by the Czech Hydrometeorological Institute (CHMI). The aim was to improve the knowledge of natural background levels and anthropogenic influences on the content of radionuclides in sediments and suspended matter. The results of the monitoring for the period 2000-2010 and 2001-2010, respectively, are evaluated in the paper.

\section{Methods}

The monitoring network of river bottom sediments covered the Czech Republic and included 44 river sites (hereinafter referred to as "basic network"). Based on the evaluation of the results in 2004 [5], the monitoring was extended by an additional 33 sites in 2006-2008 (hereinafter referred to as "extended network"), which cover the areas of former uranium and coal mining and processing. The sampling was carried out mainly by staff of CHMI and since 2006 the new sites were also sampled 
by staff of river basin companies and the T. G. Masaryk Water Research Institute (TGM WRI). The frequency of the sampling was twice per year.

Suspended matter were sampled by using a mobile centrifuge ALFA LAVAL WSB 203B-34 with a pump ALFA LAVAL IP 200 and maximal power $1800 \mathrm{l} / \mathrm{s}$ since the year 2001 [6]. In the period 2001-2005, the sampling was carried out in the same monitoring network as of river bottom sediments (basic network). The monitoring was narrowed to ten selected sites in 2006.

Grain size of the sediment samples was generally less than $2 \mathrm{~mm}$. Samples were analyzed at the Radiological Laboratory of the TGM WRI. Sediment samples were dried at $105^{\circ} \mathrm{C}$, hermetically sealed in containers and measured for the activities of caesium-137 $\left({ }^{137} \mathrm{Cs}\right)$, potassium-40 $\left({ }^{40} \mathrm{~K}\right)$, radium-226 $\left({ }^{226} \mathrm{Ra}\right)$ and radium-228 $\left({ }^{228} \mathrm{Ra}\right)$ by using gamma-spectrometric methods in accordance with Czech National Standard ISO 10703 (75 7630) [7]. Samples of suspended matter were measured for the activities of ${ }^{137} \mathrm{Cs},{ }^{226} \mathrm{Ra}$ and ${ }^{228} \mathrm{Ra}$. The amount of dry sample was about $0.5 \mathrm{~kg}$ (sediments) and 1 - $25 \mathrm{~g}$ (suspended matter) respectively. The results were expressed in $\mathrm{Bq} / \mathrm{kg}$ dry sample. The minimum detectable activities (MDA) in the sediments at the $95 \%$ level of significance were approx. $0.5 \mathrm{~Bq} / \mathrm{kg}$ for ${ }^{137} \mathrm{Cs}, 10 \mathrm{~Bq} / \mathrm{kg}$ for ${ }^{40} \mathrm{~K}$, and $2 \mathrm{~Bq} / \mathrm{kg}$ for the radium radioisotopes. The MDA in the suspended matter at the $95 \%$ level of significance was approx. 5
$\mathrm{Bq} / \mathrm{kg}$ for ${ }^{137} \mathrm{Cs}, 20 \mathrm{~Bq} / \mathrm{kg}$ for the ${ }^{226} \mathrm{Ra}$ and $30 \mathrm{~Bq} / \mathrm{kg}$ for ${ }^{228} \mathrm{Ra}$.

Values below the MDA were included in the assessment as they were assumed to equal the MDA. The measured values were used for calculation of annual average activities. Comprehensive assessment of radionuclides in river sediments was done for basic network for the period 2000-2010. The extended network was included only for assessment of impacts of former uranium mining and processing. Assessment of radionuclides in the suspended matter was done only for ten sites where the monitoring was carried out for the whole period 2001-2010.

The monitoring network of river bottom sediments and suspended matter is shown in Figure 1.

\section{Results and Their Evaluation}

\subsection{Caesium-137}

The concentrations of artificial radionuclides were assessed by using ${ }^{137} \mathrm{Cs}$, which represents the residual contamination in the environment after nuclear weapons tests in the atmosphere, mainly in the 1950s and 1960s, and also the nuclear reactor accident at Chernobyl in 1986. The half-life of ${ }^{137} \mathrm{Cs}$ is 30.2 y [8]. Annual average activities in river sediments at the monitored sites ranged from 11.4 to $17.5 \mathrm{~Bq} / \mathrm{kg}$, with an average of $14.0 \mathrm{~Bq} / \mathrm{kg}$.

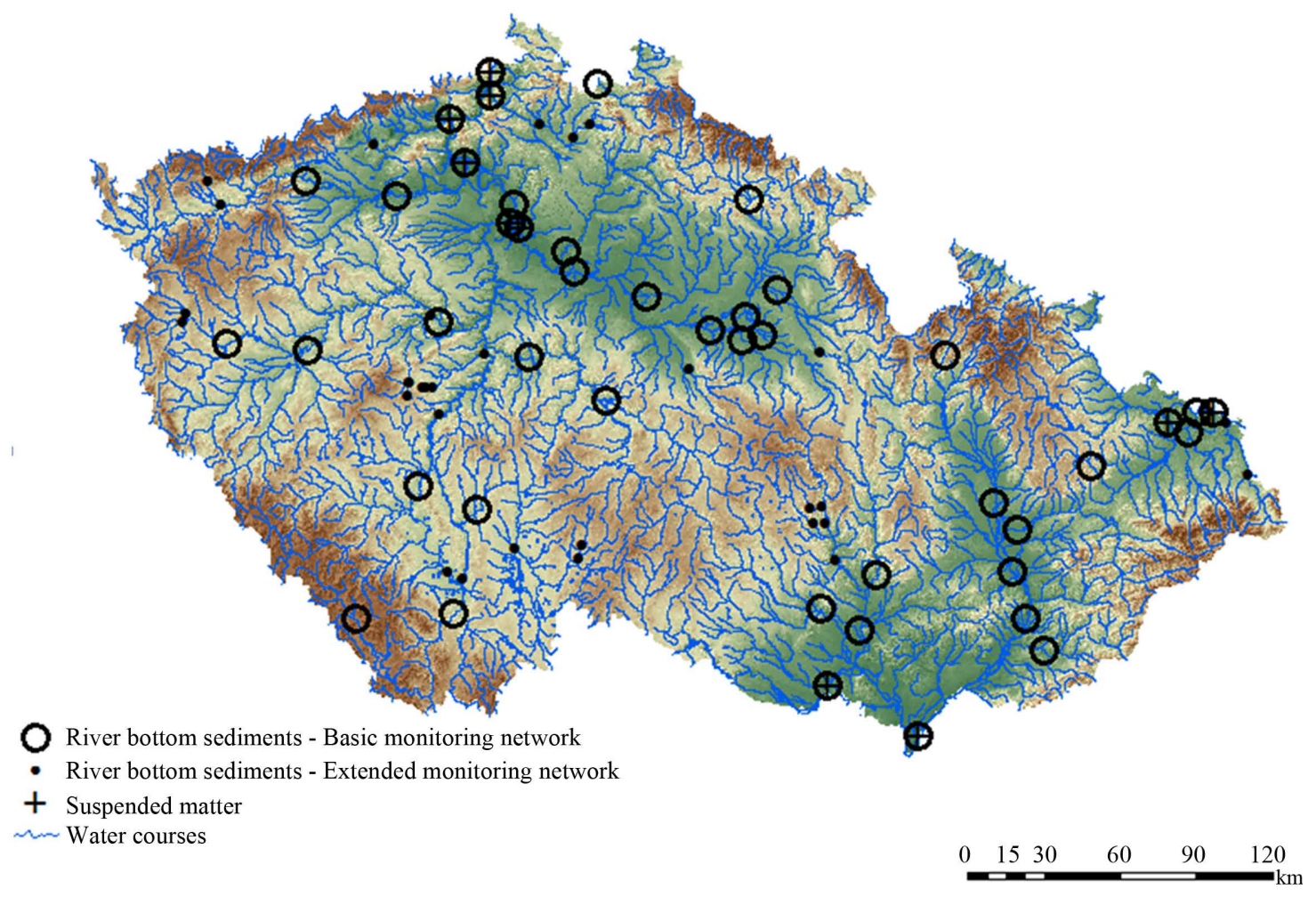

Figure 1. Map of sampling sites. 
Differences in the ${ }^{137} \mathrm{Cs}$ concentrations of sediment between the monitored sites correspond to the available information on the distribution in the Czech Republic after the accident at the Chernobyl nuclear reactor [9]. The highest activities of ${ }^{137} \mathrm{Cs}$, with an average of 87.6 $\mathrm{Bq} / \mathrm{kg}$ and range from 38.9 to $124 \mathrm{~Bq} / \mathrm{kg}$, were detected at the Topělec site on the Otava River.

Annual average activities in suspended matter ranged from 16.8 to $31.4 \mathrm{~Bq} / \mathrm{kg}$, with an average of $25.0 \mathrm{~Bq} / \mathrm{kg}$. The average activity of ${ }^{137} \mathrm{Cs}$ in the suspended matter was nearly two times higher than that in river sediments.

Further, the assessment of ratio of ${ }^{137} \mathrm{Cs}$ activities in suspended matter and sediments at individual sites was performed. The ratio ranged from 1 to 36.8, with an average 6.2. The activity of ${ }^{137} \mathrm{Cs}$ was higher in suspended matter than in river sediments at all sites.

The data from the basic network were analysed for possible time trends in the ${ }^{137}$ Cs values (Equation (1)). Statistical significance of regression curve was tested by using F-test. Effective half-life was calculated according to Equations (2) and (3) $[10,11]$ :

$$
\ln a=-\lambda_{\text {eff }} \cdot t+q
$$

where $a$ is radionuclide activity in sediments $(\mathrm{Bq} / \mathrm{kg}) ; \lambda_{\text {eff }}$, effective decay constant of ${ }^{137} \mathrm{Cs}(1 / \mathrm{y}) ; t$, time (y); and $q$, natural logarithm of radionuclide activity in sediments (suspended matter) at the beginning of observation $(\mathrm{Bq} / \mathrm{kg})$.

$$
T_{\text {eff }}=\ln 2 / \lambda_{\text {eff }}
$$

where $T_{\text {eff }}$ is effective half-life of ${ }^{137} \mathrm{Cs}(\mathrm{y})$.

$$
1 / T_{\text {eсо }}=1 / T_{\text {eff }}-1 / T_{P}
$$

where $T_{\text {eco }}$ is ecological half-life of ${ }^{137} \mathrm{Cs}(\mathrm{y})$ and $T_{P}$ is physical half-life of ${ }^{137} \mathrm{Cs}(\mathrm{y})$.

The annual average values were used for determining the effective half-life of ${ }^{137} \mathrm{Cs}$ in sediments $23.8 \mathrm{y}$ and ecological half-life 112 y (see Figure 2).

The average decrease in the ${ }^{137} \mathrm{Cs}$ in sediments exceeds that of the physical half-life ( $30.2 \mathrm{y}$ ). We assume that the quicker reduction of ${ }^{137} \mathrm{Cs}$ is caused by natural fluvial and biological processes, and thus that the effective and ecological half-lives are less than the radioactivity decay.

The annual average values of ${ }^{137} \mathrm{Cs}$ in suspended matter were used for determining the effective half-life of ${ }^{137} \mathrm{Cs}$ in suspended matter $11.4 \mathrm{y}$ and ecological half-life 18.4 y (Figure 2). Observed decrease of ${ }^{137} \mathrm{Cs}$ in suspended matter was faster than in sediments.

\subsection{Potassium-40}

${ }^{40} \mathrm{~K}$ is a natural isotope with very long half-life $(1.28 \times$ $10^{9} \mathrm{y}$ ) (with an abundance of $0.0118 \%$ ) and classified among the so-called primordial radionuclides (radionuc- lides which arose with the emergence of the Earth). In the Earth's crust, it is dispersed homogeneously $[8,12]$. Observed annual average values ranged from 513 to 605 $\mathrm{Bq} / \mathrm{kg}$, with an average of $570 \mathrm{~Bq} / \mathrm{kg}$. In the monitoring period, the observed values did not exhibit any significant trend, using Equation (1) (Figure 3).

The results of the monitoring programme in the Czech Republic are in good agreement with the range of ${ }^{40} \mathrm{~K}$ activities reported in the literature for sediments and suspended matter, which is $500-700 \mathrm{~Bq} / \mathrm{kg}$ [13].

The assessment of ${ }^{40} \mathrm{~K}$ in suspended matter was not performed.

\subsection{Radium-226 and 228}

The isotopes ${ }^{226} \mathrm{Ra}$ and ${ }^{228} \mathrm{Ra}$ are among the most representative of the natural decay series of uranium and thorium, with half-lives of $1600 \mathrm{y}$ and $5.7 \mathrm{y}$, respectively [8].

Development of annual average ${ }^{226} \mathrm{Ra}$ activities in river sediments and suspended matter for the period 2000-2010 and 2001-2010 respectively is showed in the Figure 4.

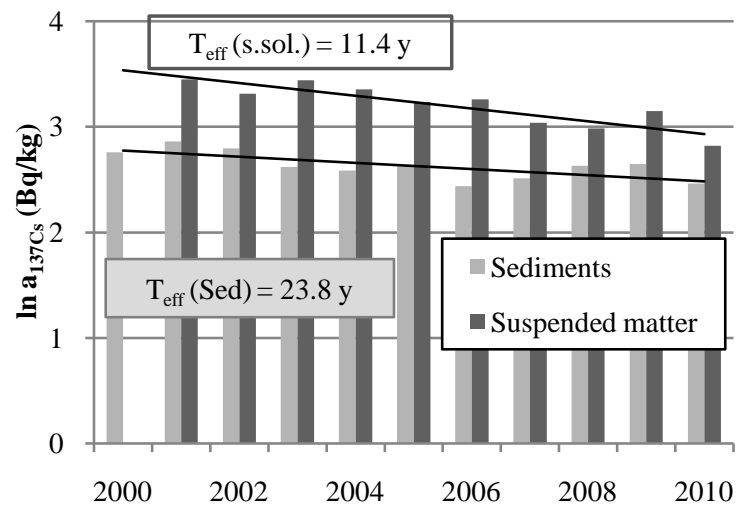

Figure 2. The decrease in annual average ${ }^{137} \mathrm{Cs}$ activities in river sediments and suspended matter for the period 2000-2010 and 2001-2010 respectively.

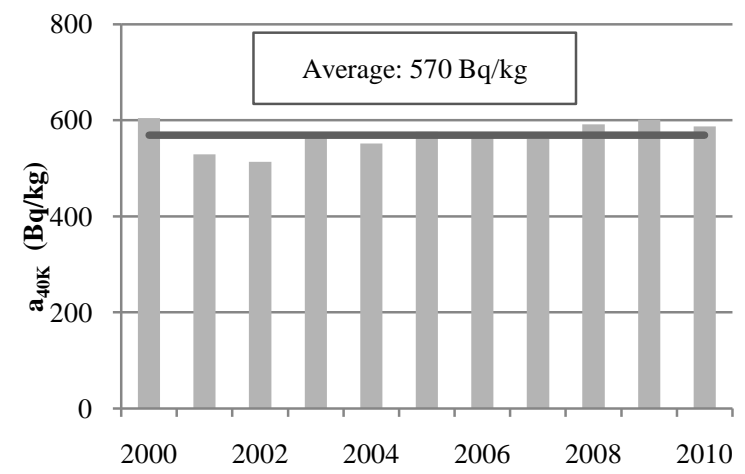

Figure 3. Annual average ${ }^{40} \mathrm{~K}$ activities in river sediments for the period 2000-2010. 


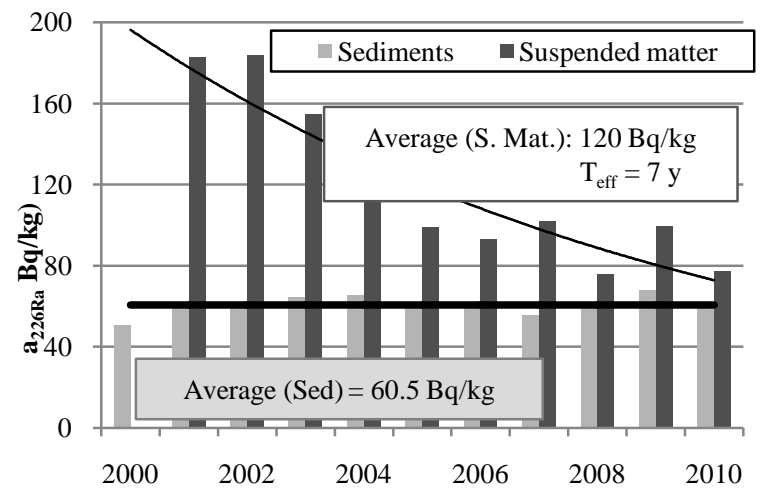

Figure 4. Development of annual average ${ }^{226} \mathrm{Ra}$ activities in river sediments and suspended matter for the period 2000-2010 and 2001-2010 respectively.

Annual average values of ${ }^{226} \mathrm{Ra}$ in river sediments for the whole territory of Czech Republic ranged from 50.8 to $67.9 \mathrm{~Bq} / \mathrm{kg}$, with an average of $60.5 \mathrm{~Bq} / \mathrm{kg}$. In the monitoring period 2000-2010, the observed annual average values for basic network did not exhibit any significant trend, using Equation (1).

Annual average values of ${ }^{226} \mathrm{Ra}$ in suspended matter ranged from 75.5 to $184 \mathrm{~Bq} / \mathrm{kg}$, with an average of 120 $\mathrm{Bq} / \mathrm{kg}$. In the monitoring period 2001-2010, the observed annual average values were used for determining the effective half-life of ${ }^{226} \mathrm{Ra}$ in suspended matter $7 \mathrm{y}$, using Equation (1).

Development of annual average ${ }^{228} \mathrm{Ra}$ activities in river sediments and suspended matter for the period 2000-2010 and 2001-2010 respectively is showed in the Figure 5.

Anthropogenic pollution of the aquatic environment by ${ }^{228} \mathrm{Ra}$ is unlikely, because thorium ores are not mined in the Czech Republic.

Annual average values of ${ }^{228} \mathrm{Ra}$ in river sediments ranged from 40.2 to $53.9 \mathrm{~Bq} / \mathrm{kg}$, with an average of 47.2 $\mathrm{Bq} / \mathrm{kg}$. In the monitoring period 2000-2010, the observed annual average values of ${ }^{228} \mathrm{Ra}$ for basic network did not exhibit any significant trend, using Equation (1).

Annual average values of ${ }^{228} \mathrm{Ra}$ in suspended matter ranged from 65 to $158 \mathrm{~Bq} / \mathrm{kg}$, with an average of 87.9 $\mathrm{Bq} / \mathrm{kg}$. In the monitoring period 2001-2010, the observed annual average values were used for determining the effective half-life of ${ }^{228} \mathrm{Ra}$ in suspended matter $9.7 \mathrm{y}$, using Equation (1).

Observed values correspond to the natural occurrence of ${ }^{228} \mathrm{Ra}$ in watercourses.

Activities of ${ }^{228} \mathrm{Ra}$ in suspended matter are in greater range than activities in sediments. Also decrease of activity of ${ }^{228} \mathrm{Ra}$ in suspended matter exceeded that of the physical half-life at most sites. This we attribute to presence of parent radionuclide ${ }^{232} \mathrm{Th}$ with physical half-life

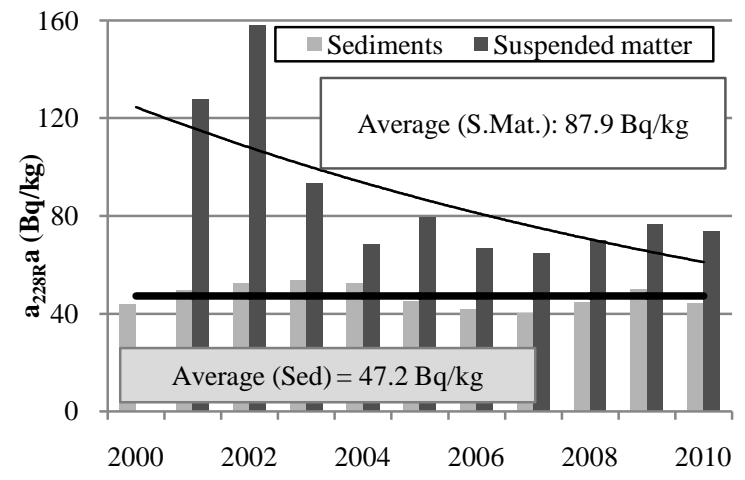

Figure 5. Development of annual average ${ }^{228}$ Ra activities in river sediments and suspended matter for the period 2000-2010 and 2001-2010 respectively.

of $1.4 \times 10^{10} \mathrm{y}$ [8]. However decrease of activity ${ }^{228} \mathrm{Ra}$ should be studied in more details.

Additionally was carried out monitoring activity of ${ }^{226} \mathrm{Ra}$ and ${ }^{228} \mathrm{Ra}$ in sediments at sites of former uranium (and coal) mining and processing in the period 2006-2008 (extended network). Observed annual average values ${ }^{226} \mathrm{Ra}$ ranged at these sites from 102 to $133 \mathrm{~Bq} / \mathrm{kg}$, with an average of $123 \mathrm{~Bq} / \mathrm{kg}$. Observed annual average values of ${ }^{228} \mathrm{Ra}$ ranged from 42.5 to $54.4 \mathrm{~Bq} / \mathrm{kg}$, with an average of $49.8 \mathrm{~Bq} / \mathrm{kg}$. While average activity of ${ }^{228} \mathrm{Ra}$ for extended network was same as that in other (basic network), average activity of ${ }^{226} \mathrm{Ra}$ was two times greater.

The ratio of ${ }^{226} \mathrm{Ra}$ and ${ }^{228} \mathrm{Ra}$ activities in suspended matter and in sediments was assessed. The ratio of ${ }^{226} \mathrm{Ra}$ activities ranged from 0.3 to 4.6 with an average 1.9. The ratio of ${ }^{228} \mathrm{Ra}$ activities ranged from 0.7 to 6.9 with an average 2.3. Activity of ${ }^{226} \mathrm{Ra}$ and ${ }^{228} \mathrm{Ra}$ was higher in suspended matter in $82 \%$ and $94 \%$ respectively.

Hanslík [14] proposed that it is possible to use the ${ }^{226} \mathrm{Ra}:{ }^{228} \mathrm{Ra}$ ratio to identify the degree of radionuclide contamination in the environment from uranium ore (and coal) mining activities. The ratio is around 1.0 in natural samples, while in areas affected by uranium ore mining, it is significantly higher. The activity of ${ }^{226} \mathrm{Ra}$ is increased as a result of contamination, while the activity of ${ }^{228} \mathrm{Ra}$ corresponds to the natural radium levels. On this basis, Hanslík [14] proposed five classes of river sediment contamination by ${ }^{226} \mathrm{Ra}$ according to the ${ }^{226} \mathrm{Ra}:{ }^{228} \mathrm{Ra}$ ratio (see Table 1).

These classes were used for classification of river sediments collected in the individual sites in the period 2000-2010. Results from extended network were included to the assessment too. The numbers of the sites in the individual classes are shown in Figure 6.

In the period 2000-2005 and 2009-2010, most of the sites were classified as class I ( $84 \%-91 \%)$, i.e. as uncontaminated. In the period 2006-2008, the inclusion of the sites affected by former mining and processing of 
Table 1. Classification of river sediments (and suspended matter) contaminated by ${ }^{226} \mathrm{Ra}$ into classes $\mathrm{I}-\mathrm{V}$ according to the ratio of the activities of ${ }^{226} \mathrm{Ra}$ and ${ }^{228} \mathrm{Ra}$ [14].

\begin{tabular}{|c|c|c|}
\hline${ }^{226} \mathrm{Ra}$ & Class & Description \\
\hline$\leq 1.5$ & I & Natural occurrence of natural radionuclides \\
\hline$>1.5-2.0$ & II & $\begin{array}{l}\text { Moderate contamination by wastes from uranium } \\
\text { industry, coal mining, industrial wastes }\end{array}$ \\
\hline$>2.0-5.0$ & III & $\begin{array}{l}\text { Contamination by wastes } \\
\text { from uranium industry }\end{array}$ \\
\hline$>5.0-10.0$ & IV & $\begin{array}{l}\text { High contamination by wastes } \\
\text { from uranium industry }\end{array}$ \\
\hline$>10$ & V & $\begin{array}{l}\text { Extremely high contamination by } \\
\text { wastes from uranium industry }\end{array}$ \\
\hline
\end{tabular}

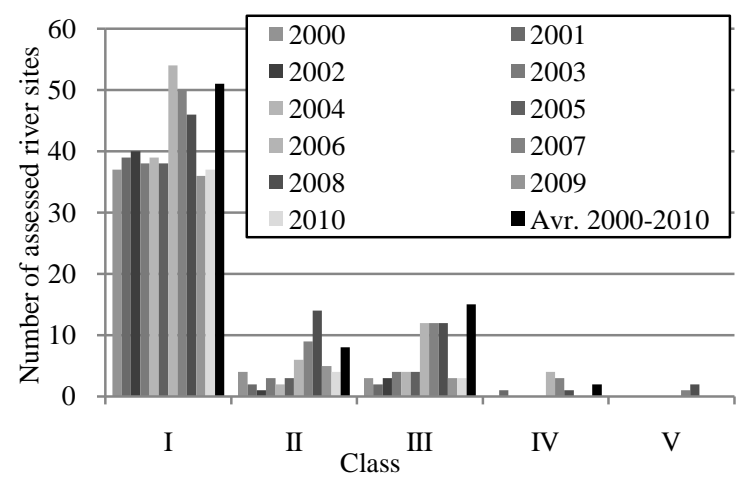

Figure 6. Classification of river sediments into Classes I-V according to the ${ }^{226} \mathrm{Ra}:{ }^{228} \mathrm{Ra}$ ratio for annual average activities (see Table 1 for class description).

uranium ore has been reflected by an increase in the representation of contaminated classes.

These classes were used also for classification of suspended matter. The numbers of the sites in the individual classes are shown in Figure 7. Most of the sites were classified as class I (from $50 \%$ to $100 \%$ ) too.

The ratio of ${ }^{226} \mathrm{Ra}$ and ${ }^{228} \mathrm{Ra}$ activities from 5 selected sites with former uranium mining and processing was in average higher in sediments than in suspended matter. Only at one site was evaluated ratio higher in suspended matter. We think it is because of better conditions of water and stopping of mining and on-going mining water treatment respectively.

\subsection{Natural Background Levels}

The average values were used further to determine natural background levels of radionuclides in the Czech Republic. For ${ }^{40} \mathrm{~K}$, the natural background level was estimated to be $570 \mathrm{~Bq} / \mathrm{kg}$. To evaluate the background level for ${ }^{226} \mathrm{Ra}$, the river sites affected by human activities (mining and processing uranium ore, coal) were eliminated from the assessment, and only river sites falling

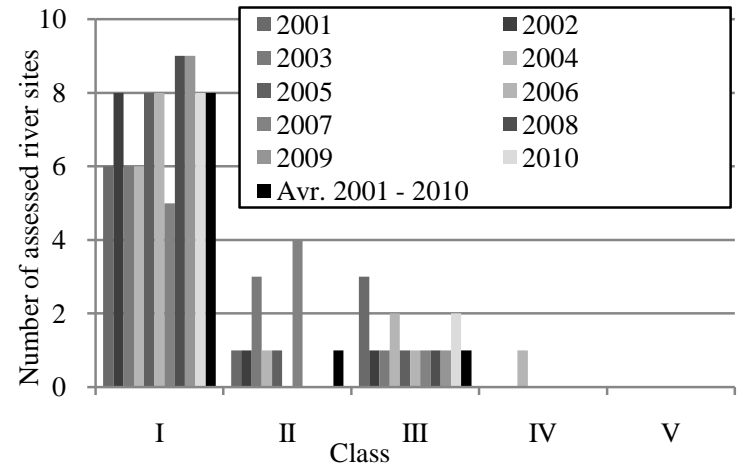

Figure 7. Classification of suspended matter into Classes $\mathrm{I}-\mathrm{V}$ according to the ${ }^{226} \mathrm{Ra}:{ }^{228} \mathrm{Ra}$ ratio for annual average activities.

into class I were used for the analysis. The average natural background values for ${ }^{226} \mathrm{Ra}$ and ${ }^{228} \mathrm{Ra}$ in sediments were essentially identical at $47.8 \mathrm{~Bq} / \mathrm{kg}$ for ${ }^{226} \mathrm{Ra}$ and 47.2 for ${ }^{228} \mathrm{Ra}$. In suspended matter it was $86.5 \mathrm{~Bq} / \mathrm{kg}$ for ${ }^{226} \mathrm{Ra}$ and $87.9 \mathrm{~Bq} / \mathrm{kg}$ for ${ }^{228} \mathrm{Ra}$. The uncertainty of the background values was expressed as the standard deviation.

\section{Conclusions}

Activities of ${ }^{137} \mathrm{Cs},{ }^{40} \mathrm{~K},{ }^{226} \mathrm{Ra}$ and ${ }^{228} \mathrm{Ra}$ in river bottom sediments and suspended matter were monitored during the period 2000-2010 and 2001-2010 respectively. The mean concentrations of ${ }^{137} \mathrm{Cs}$ in the sediments were 14.0 $\mathrm{Bq} / \mathrm{kg}$ and $25.0 \mathrm{~Bq} / \mathrm{kg}$ in the suspended matter. This reflects the residual contamination after nuclear weapons tests and the Chernobyl accident. Annual average values were analyzed for possible time trends in the monitored period. Evaluated effective half-lives of ${ }^{137} \mathrm{Cs}$ in the river sediments were $23.8 \mathrm{y}$ and $11.4 \mathrm{y}$ in the suspended matter respectively. The assessment of ratio of ${ }^{137} \mathrm{Cs}$ activities in suspended matter and sediments at individual sites was performed. The ratio ranged from 1 to 36.8, with an average 6.2. The activity of ${ }^{137} \mathrm{Cs}$ was higher in suspended matter than in river sediments at all assessed sites.

Natural background levels in river sediments were 570 $\mathrm{Bq} / \mathrm{kg}$ for ${ }^{40} \mathrm{~K}$, 47.8 Bq/kg for ${ }^{226} \mathrm{Ra}$ and $47.2 \mathrm{~Bq} / \mathrm{kg}$ for ${ }^{228} \mathrm{Ra}$. In suspended matter it was $86.5 \mathrm{~Bq} / \mathrm{kg}$ for ${ }^{226} \mathrm{Ra}$ and $87.9 \mathrm{~Bq} / \mathrm{kg}$ for ${ }^{228} \mathrm{Ra}$.

In the monitoring period, the observed annual average values of ${ }^{40} \mathrm{~K},{ }^{226} \mathrm{Ra}$ and ${ }^{228} \mathrm{Ra}$ in river sediments from the whole territory of Czech Republic did not exhibit any significant trend. The decrease of annual average values of ${ }^{226} \mathrm{Ra}$ and ${ }^{228} \mathrm{Ra}$ in suspended matter was observed. Evaluated effective half-lives of ${ }^{226} \mathrm{Ra}$ and ${ }^{228} \mathrm{Ra}$ in suspended matter were $7 \mathrm{y}$ and $9.7 \mathrm{y}$.

The ratio of ${ }^{226} \mathrm{Ra}$ and ${ }^{228} \mathrm{Ra}$ activities in suspended 
matter and in sediments was assessed. The ratio of ${ }^{226} \mathrm{Ra}$ activities ranged from 0.3 to 4.6 with an average 1.9. The ratio of ${ }^{228} \mathrm{Ra}$ activities ranged from 0.7 to 6.9 with an average 2.3. Activity of ${ }^{226} \mathrm{Ra}$ and ${ }^{228} \mathrm{Ra}$ was higher in suspended matter in $82 \%$ and $94 \%$ respectively.

The river bottom sediments are still contaminated by ${ }^{226} \mathrm{Ra}$ which stems from mining and processing of uranium ore. Contamination by ${ }^{226} \mathrm{Ra}$ can be assessed by using the ${ }^{226} \mathrm{Ra}:{ }^{228} \mathrm{Ra}$ ratio, which is up to 1.5 for unaffected river sites, and exceeds this value for the affected sites. This approach can be used as a complementary assessment to that based solely on the activity of ${ }^{226} \mathrm{Ra}$ to identify sites contaminated by uranium mining and processing.

\section{Acknowledgements}

This paper was prepared with the support of the project MŽP CR 0002071101.

\section{REFERENCES}

[1] A. Mansfeld and E. Hanslík, "The Migration of Radionuclides from Nuclear-Power Plants in Surface Waters," Report TGM WRI, Prague, 1983 (in Czech).

[2] P. Beneš and L. Nondek, "Analysis of the Contamination of River Sediments in the Elbe River Basin,” Final Report for EU Elbe Project 03.02.07 PF UK, Praha, 1993.

[3] E. Hanslík, "Impact of Temelín Nuclear Power Plant on hydrosphere,” Research for Practice: Workbook 34, T. G. M. WRI, Prague, 1996 (in Czech).

[4] E. Hanslík, A. Mansfeld, J. Justýn, V. Moucha and P. Šimonek, "Impact of Uranium Ore Mining on the Development of Contamination of Hydrosphere of the Ploučnice River during 1966-2000,” Research for Practice: Workbook 45, TGM WRI, Prague, 2002 (in Czech).

[5] E. Hanslík, E. Kalinová, M. Brtvová, D.Ivanovová, B. Sedlářová, J. Svobodová, V. Jedináková-Křížová, M. Rieder, J. Medek, K. Forejt, L. Vondrák, K. Jahn and J. Jusko, "Radium Isotopes in River Sediments of Czech
Republic," Limnologica-Ecology and Management of Inland Waters, Vol. 35, No. 3, 2005, pp. 77-184.

[6] M. Rieder and P. Benčík, "Sampling of Suspended Matter by Mobile Sampler in Profiles of National Monitoring Network of Monitoring Water Quality in Rivers," Proceedings of XVIII. Conference on Radionuclides and Ionizing Radiation in Water Management. ČVTVS Praha, České Budějovice, 2001(in Czech).

[7] CNS ISO 10703 Water Quality-Determination of the Activity Concentration of Radionuclides-Method by High Resolution Gamma-Ray Spectrometry, ČNI, 2008 (in Czech)

[8] C. M. Ledererand V. S. Shirley, “Table of Isotopes,” 7th Edition, Wiley-Inter-Science Publication, New York, 1978.

[9] E. Hanslík, V. Jedináková-Kř́ížová, D. Ivanovová, E. Kalinová, B. Sedlářová and P. Šimonek, "Observed HalfLives of ${ }^{3} \mathrm{H},{ }^{90} \mathrm{Sr}$ and ${ }^{137} \mathrm{Cs}$ in Hydrosphere in the Vltava River Basin (Bohemia),” Journal of Environmental Radioactivity, Vol. 81, No. 2-3, 2005, pp. 307-320. http://dx.doi.org/10.1016/j.jenvrad.2004.01.042

[10] E. Hanslík, P. Šimonek and B. Sedlářová, "Contamination of CR Water after Chernobyl,” Sovak, Vol. 9, No. 4, 2000, pp. 99-102 (in Czech).

[11] J. T. Smith and N. A. Beresford, "Chernobyl Catastrophe and Consequences," Praxis Publishing Ltd, Chichester, 2005.

[12] J. Švec, A. Heribanová, J. Novotná, J. Filip, L. Mrázek, H. Žárská, O. Bezděková, J. Rada, V. Hušák and Z. Pašková, "Protection When Working with Sources of Ionizing Radiation," Proceedings of Textbooks, Dumtechniky Ostrava, SPOL. SR. O., 2003 (in Czech).

[13] H.Mundschenk, “Occurrence and Behaviour of Radionuclides in the Moselle River-Part I: Entry of Natural and Artificial Radionuclides”, Journal of Environmental Radioactivity, Vol. 30, No. 3, 1996, pp. 199-213. http://dx.doi.org/10.1016/0265-931X(95)00009-Y

[14] E. Hanslík, "Radioactive substances,” Newsletter of Main Research and Coordination Department for Elbe Project No. 14, T.G.M WRI, Prague, 1997 (in Czech). 